\title{
Wool characteristics of Batur sheep in Banjarnegara District, Central Java
}

\author{
Bess Tiesnamurti*, Gresy Eva Teresia, and Zuratih \\ Indonesian Centre for Animal Research and Development, Jalan Raya Pajajaran Kav. E-59, Bogor \\ 16152, West Java, Indonesia
}

\begin{abstract}
The study's objective was to investigate the different types of coat cover from Batur sheep of Banjarnegara district in Central Java using 113 sheep belongs to 13 people member of Mulya Jaya farmers group. Sheep were raised at the centre of horticulture at the Batur-Dieng plateau. The main vegetable type planted in the area were carrot, potato and cabbage. The variables observed in the study were wool cover (score 1-9), the length of wool $(\mathrm{cm})$, breed, sex, age and sheep body weight $(\mathrm{kg})$. The data were analyzed using a general linear model, with the dependent variable were body weight and wool length whereas the independent variable were sex, location of the study, farmers, breed, sex and age. The result showed that $77.9 \%$ of sheep has wool distribution (score $=0$ ), most of the sheep $(98.2 \%)$ has white color and only very small percentage has black, brown color. The average body weight and wool length of Batur sheep was $41.4 \mathrm{~kg}$ (range 15-97 kg) and $6.97 \mathrm{~cm}$ (range 4-17 cm), respectively, and there was a significant $(\mathrm{P}<0.05)$ influence of farmers, breed, sex and age. The Batur sheep is a wool type sheep and still maintain the characteristic of merino sheep.
\end{abstract}

\section{Introduction}

Batur sheep is one of the breeds that have been designated as a local breed of sheep by Decree of the Minister of Agriculture Number 2916 / Kpts / OT.140 / 6/2011 dated June 17, 2011 [2]. According to its origin, the Batur sheep is a cross between Merino sheep and local sheep, which occurred during the new order around the 1980's. The adaptation process that has been going on has led to develop the Batur sheep as seen to day. The farmers use the sheep as genetic resources and sold as breed stock to farmers in Indonesia. The body weight (BW), chest girth (CG), height at whither (HW), body length (BL), and length of tail (LT) of different age group (young compared to mature sheep) were significantly affected $(\mathrm{P}<0.05)$ with average of 64.65 vs $70.76 \mathrm{~kg} ; 97.57$ vs $105.49 \mathrm{~cm} ; 61.82$ vs $64.98 \mathrm{~cm} ; 70.8$ vs $73.80 \mathrm{~cm} ; 28.45$ vs $32.03 \mathrm{~cm}$, respectively [1]. Along with the effect of age, sex has also significant influence $(\mathrm{P}<0.05)$ on the several body measurement such as body wight $(\mathrm{BW})$, body length (BL), height at whither (HW), ear length (EL) and tail length (TL) with average of 78.53 vs $63.79 \mathrm{~kg}, 79.12$ vs $69.8 \mathrm{~cm}, 68.94$ vs $60.88 \mathrm{~cm}, 10.6$ vs $9.39 \mathrm{~cm}$ and 33.83 vs $29.02 \mathrm{~cm}$, for male compared to female, respectively. Those phenotypic

* Corresponding author: besstiesnamurti@yahoo.com 
measurement was lower compared to earlier measurement made during the time of breed registration in 2011.

Previous study by [3] reported that Batur sheep is quiet a distance genetically with among five Indonesian sheep populations (Garut sheep of fighting type, Garut sheep of meat type, Purbalingga sheep, Batur sheep, and Jember sheep population). The average of observed heterozygosity (Ho) and expected heterozygosity (He) values were 0.5749 and 0.6896, respectively, while the genetic differentiation for inbreeding among population (FIS), within population (FIT) and average genetic differentiation (FST) were 0.1006, 0.1647 and 0.0712 , respectively. Genetic distance and genetic tree showed that Indonesian sheep population was distinct from Garut sheep of fighting and meat types, Purbalingga sheep, Batur sheep and Jember sheep population.

One characteristics of Batur sheep was its wool cover along the surface such as Merino sheep and their ancestry. The coat cover of Batur sheep could be of a mixture between wool and hair according to their genetic potential. A study was designed to investigate the effects of FST gene single nucleotide polymorphisms (SNP) on wool quality traits in Chinese Merino sheep (Junken Type). The study showed that FST gene was differentially expressed in adult skin between Chinese Merino sheep (Junken Type) and Suffolk sheep. Association analysis showed that SNP2 (Chr 16. 25,633,662 G>A) was significantly associated with average wool fiber diameter, wool fineness SD, and wool crimp $(\mathrm{P}<0.05)$. SNP4 (Chr 16. $25,633,569 \mathrm{C}>\mathrm{T}$ ) was significantly associated with wool fineness $\mathrm{SD}$ and $\mathrm{CV}$ of fiber diameter $(\mathrm{P}<0.05)$. The results suggest that FST influences wool quality traits and its SNPs 2 and 4 might be useful markers for marker-assisted selection and sheep breeding [4].

So far, wool of Batur sheep has not been utilized and thrown away or burnt after being shorn from the animal. Even farmers do not have regular period for shearing of the wool. However, [5] reported the study utilizing wool of Batur and Garut sheep for industrial purposes. Wool physical characteristics (WB) is important due to the potential background for utilization to certain product. The variables observed including bundle tenacity, elongation, flammability, sound and thermal insulation properties. The comparison data of sound and thermal insulation ability between board (P), board + Batur sheep wool (PWB), and board + Garut sheep wool (PWG) as well as the comparison data of flammability between WB, WG, P and nylon were observed. The result showed that WB and WG had no significant difference on their tenacity, resilient, and flammability, repectiveky. However, PWB and PWG had better sound and thermal insulation ability compared than P and wool had better flammability compated to $\mathrm{P}$ and nylon.

This study was designed to investigate the phenotype of wool characteristics from Batur sheep and the possibilities for its utilization.

\section{Materials and methods}

\subsection{Research location and animal management}

The research was conducted at Batur Sub District of Banjarnegara District of Central Java Province using sheep belong to the farmers. A total of 113 sheep from different age and sex owned by 13 farmers, member of Mulya Jaya farmers group was used for the study. Farmers were selected among 20 members of the group, due to their time allocation and willingness. The number of sheep used in this study was the total of sheep belong to the farmers. Sheep were kept intensively at communal barn and fed vegetables by products such as carrot, cabbage and also natural grass available surrounding the location. Forages was offered twice daily, in the morning and again during afternoon. Mating was conducted individually according to the estrus sign expressed by the females. 


\subsection{Variables recorded}

The variables recorded from each animal were age (I-0 : $<12$ months; I-1: $>1-2-18$ months, I-2: > 18-24 months, I-3 : > 24 months and I-4 : > 36 months), sex (male and female) of the sheep, body weight $(\mathrm{kg})$, wool distribution along the body (score 0-9), the wool density (score 1-9) and the length of wool (cm)(Table 1). The information recorded from the farmers were the number of sheep they raised, the management practices for the sheep, the feeding practices and health care monitoring.

Table 1. Wool scoring of the sheep.

\begin{tabular}{|c|c|c|}
\hline Indicator & Score & Detail \\
\hline \multirow[t]{7}{*}{ Wool Distribution ${ }^{1)}$} & & $\begin{array}{l}\text { The score is done by observing the area of coat surrounding the } \\
\text { animal }\end{array}$ \\
\hline & 0 & Totally covered with heavy wool including lower leg and face \\
\hline & 1 & Hair only \\
\hline & 3 & $\begin{array}{l}\text { Moderate to heavy wool along tops of back, shoulders and } \\
\text { rump }\end{array}$ \\
\hline & 5 & $\begin{array}{l}\text { Moderate to heavy wool along tops of back, over shoulders and } \\
\text { half way down side and rump }\end{array}$ \\
\hline & 7 & $\begin{array}{l}\text { Moderate to heavy wool over the body except not on belly, } \\
\text { down legs and head }\end{array}$ \\
\hline & 9 & $\begin{array}{l}\text { Moderate to heavy wool over body, including belly except wool } \\
\text { may or may not be on top of head, on lower leg or on fore and } \\
\text { rear flanks }\end{array}$ \\
\hline \multirow[t]{6}{*}{ Wool density $^{1)}$} & & $\begin{array}{l}\text { The score is done by observing the density of wool from each } \\
\text { sheep }\end{array}$ \\
\hline & 1 & Short slick hair (like kacang goat), no wool, hair usually $<3 \mathrm{~cm}$ \\
\hline & 3 & $\begin{array}{l}\text { Short hair with a small amount }(10-25 \%) \text { of short or long kemp } \\
\text { mixed in, length of mix about } 2-4 \mathrm{~cm}\end{array}$ \\
\hline & 5 & $\begin{array}{l}\text { Moderately long, moderately dense hair, kemp mix, about } 3-5 \\
\mathrm{~cm} \text { long, wool usually } 20-40 \% \text { of mix }\end{array}$ \\
\hline & 7 & $\begin{array}{l}\text { Long, dense wool with various amounts and length of kemp } \\
\text { and hair mixed in about } 4-6 \mathrm{~cm} \text { long, wool usually }>50 \% \text { of } \\
\text { mix }\end{array}$ \\
\hline & 9 & $\begin{array}{l}\text { Very long, very dense wool (annual unclipped growth }>6 \mathrm{~cm} \\
\text { long), may have kemp and hair mixed in, often in heavy matted, } \\
\text { greasy locks }\end{array}$ \\
\hline
\end{tabular}

Source : ${ }^{1)}[5]$

\subsection{Data analysis}

Data were analyzed using General Linear Model of SAS.10 [7] statistical package, with the following model and assumption.

Where :

$$
Y_{i j k l m n o}=\mu+A_{i}+B_{j}+C_{k}+D_{l}+E_{m}+F_{n}+\varepsilon_{i j k l m n o}
$$

\footnotetext{
$\mathrm{Y}_{\mathrm{ijklmn}} \quad:$ the observation of body weight, from $\mathrm{i}^{\text {th }}$ location, $\mathrm{j}^{\text {th }}$ farmers, $\mathrm{k}^{\text {th }}$ sheep breed, $\mathrm{l}^{\text {th }}$ sex, $\mathrm{m}^{\text {th }}$ age and $\mathrm{n}^{\text {th }}$ wool distribution,

$\mu \quad:$ general mean

A $i \quad:$ the effect of $i^{\text {th }}$ location, where $i=1,2$

B ${ }_{j} \quad:$ the effect of $j^{\text {th }}$ farmers, where $j=1, \ldots . .13$
} 


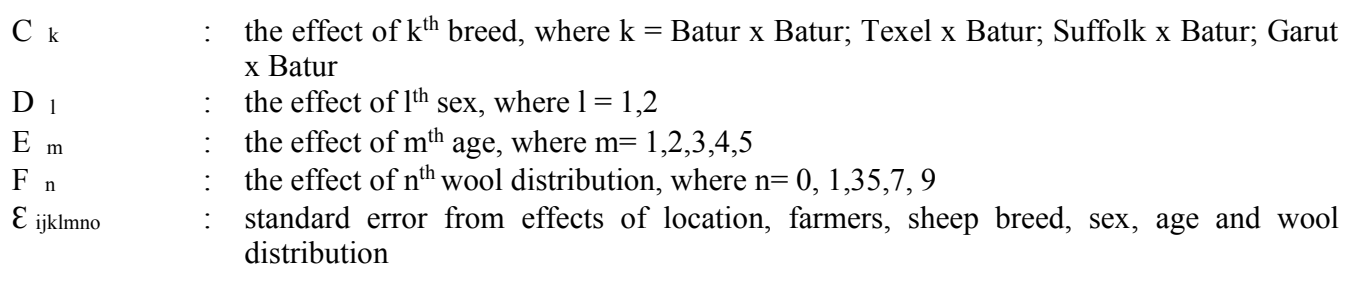

$$
Y_{i j k l m n o}=\mu+A_{i}+B_{j}+C_{k}+D_{l}+E_{m}+F_{n}+\mathcal{E}_{i j k l m n o}
$$

Where :

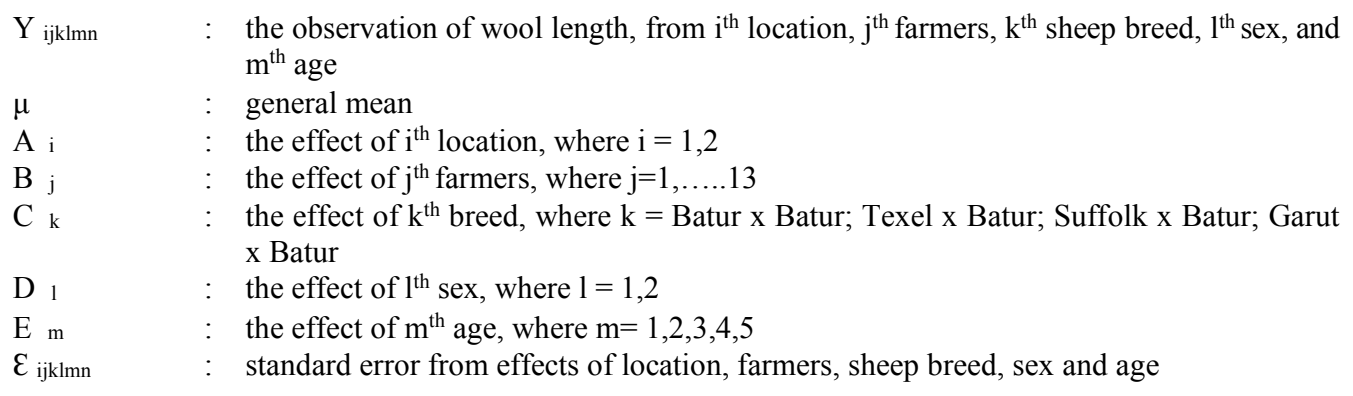

\section{Results and discussion}

\subsection{The general condition of sheep management}

This study found out that $56.6 \%$ of sheep in the population was young age (I-0) and $30 \%$ of them was of adult age (I-4) whereas $13.2 \%$ of the population was between I-1 to I-3. This type of sheep population can be considered to be vulnarable, since only $13.2 \%$ of the population was in active reproduction according to the age. On the other hand, $30 \%$ of the population was aged more than 4 years, usually the reproduction performance was slower compared to ewes between age of I-1 to I-3. This situation could happen because of high selling rate from the population and the replacement was not counducted immediately.

The average ownership of the Batur sheep from 13 farmers was 8.7 heads and range from 3 to 28 heads. This situation reflected how farmers put sheep as important belongings beside their other activities as horticulture farmers. According to the breed identification and based on the history of the mating (information from the farmer), $92.9 \%$ of the sheep in the study was classified as Batur sheep, and only small percentage of the individual were known as crossbred between Garut x Batur (1.7\%), crossbred between Suffolk x Batur $(2.6 \%)$ as well as a crossbred between Texel x Batur (3.5\%).

The Batur sheep has already been awarded as local breed, and accordingly, the mating should be conducted with Batur rams as well. However some farmers prefer to breed the Batur female with Garut or Texel rams with the expectation that the off spring will have better performance and higher body weight, which in turn offer a better price. In addition, the Garut sheep from West Java was originated from the crossing between Merino, Fat Tailed sheep and local sheep during the colonial era around 1900's. Whereas the Wonosobo sheep were originated from Texel sheep that has been adapted during the distribution. This uncontrolled cross breeding action will contaminate the purity of Batur sheep and in the future has to be sorted out with the policy from the local government. Otherwise if the 
practices are still running, the Batur sub district or Banjarnegara can no longer be awarded as the center of breed stock for Batur sheep.

Usually farmers judged the purity of Batur sheep by the appearance of wool distribution along the body, face and legs of the sheep, the height of the sheep also by the type of the head. Most Batur sheep was of white coat cover, however only very small percentage of them has black colour. The crossing between Garut and Batur sheep will generate black and brown spotted along the body.

\subsection{The wool distribution, wool density and average of wool length}

The highest percentage (79\%) of wool distribution was of score 0 (sheep totally covered with heavy wool including lower leg and face), whereas $20 \%$ of sheep has wool distribution score of 9 (moderate to heavy wool over the body, including belly except wool may or may not be on top of head, on lower leg or on fore and rear flanks), and only $0.9 \%$ of sheep has wool distribution score of 7 (moderate to heavy wool over the body except not on belly, down legs and head)(Figure 1). This figure is of interest, reflected the performance of merino ancestor from the appearance of the coat cover.

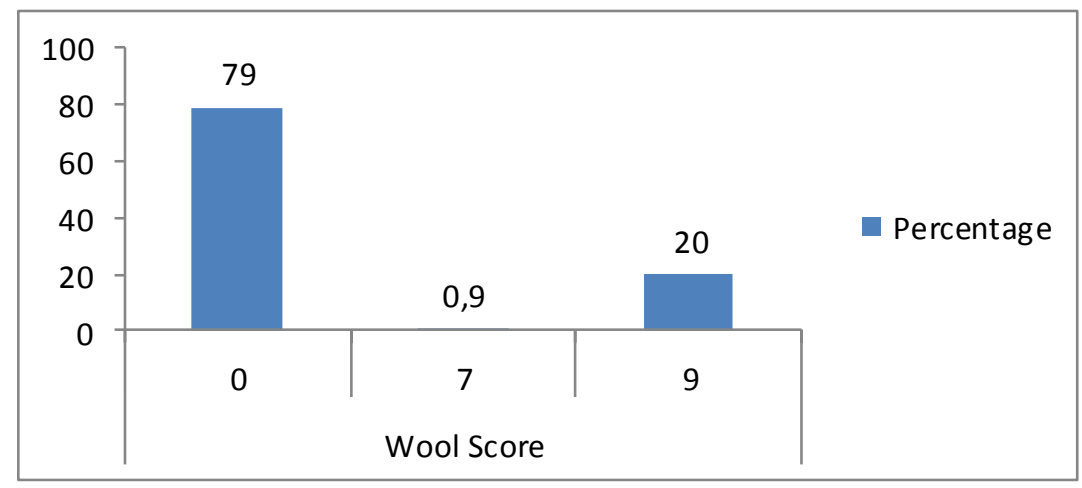

Fig. 1. The percentage of wool distribution

The average wool length of the sheep was $6.97 \mathrm{~cm}$ with coefficient of variation of $26.3 \%$ and significant influence $(\mathrm{P}<0.05)$ of breed and sex. Among the sheep breed, crossing between Suffolk x Batur has the longest wool $(12 \mathrm{~cm})$, then followed by crossing between Garut and Batur sheep $(9.0 \mathrm{~cm})$, crossing between Texel and Batur sheep $(8.75$ $\mathrm{cm}$ ) and Batur and Batur sheep (6.62), respectively. Female has longer wool staple compared to male sheep. The regular wool shearing practice by farmers was done every six months and all of the farmers mention that wool was not been used. The analysis of varian of the body weight and wool length is shown in Table 2. Body weight and wool length of Batur sheep is indicated in Table 3. 
Table 2. The analysis of variance of the body weight and wool length.

\begin{tabular}{|l|l|l|l|l|l|l|}
\hline \multirow{2}{*}{ Source } & \multicolumn{2}{c|}{ Body weight } & \multicolumn{3}{c|}{ Wool Length } \\
\cline { 2 - 7 } & $\begin{array}{l}\text { Mean } \\
\text { Square }\end{array}$ & F Value & $\operatorname{Pr}>$ F & $\begin{array}{l}\text { Mean } \\
\text { Square }\end{array}$ & F Value & $\operatorname{Pr}>$ F \\
\hline Location & 0.98 & 0.01 & 0.93 & 6.48 & 1.94 & 0.17 \\
\hline Farmer & 758.45 & 5.08 & $<0.0001^{* *}$ & 4.7 & 1.4 & 0.23 \\
\hline Breed & 1129.44 & 7.57 & $0.0001^{*}$ & 14.9 & 4.45 & $0.009^{*}$ \\
\hline Sex & 746.88 & 5.01 & $0.0277^{*}$ & 14.98 & 4.47 & $0.04^{*}$ \\
\hline Age & 4658.14 & 31.23 & $<0.0001^{* *}$ & 5.02 & 1.5 & 0.22 \\
\hline $\begin{array}{l}\text { Wool } \\
\text { distribution }\end{array}$ & 158.84 & 1.07 & 0.348 & 0.13 & 0.04 & 0.84 \\
\hline
\end{tabular}

Note : $*=$ significant difference at $\mathrm{P}<0.05$; and $* *=$ significant difference at $\mathrm{P}<0.01$

Table 3. Body weight and wool length of Batur sheep

\begin{tabular}{|l|c|c|c|}
\hline \multicolumn{1}{|c|}{ Parameter } & $\mathrm{n}$ & Body Weight $(\mathrm{kg})$ & Wool Length $(\mathrm{cm})$ \\
\hline Breed & & & $6.62^{\mathrm{b}}$ \\
\hline Batur x Batur & 105 & $41.17^{\mathrm{a}}$ & $8.75^{\mathrm{a}, \mathrm{b}}$ \\
\hline Texel x Batur & 5 & $31.00^{\mathrm{b}}$ & $12.00^{\mathrm{a}}$ \\
\hline Suffolk x Batur & 2 & $27.00^{\mathrm{a}}$ & $9.00^{\mathrm{a}, \mathrm{b}}$ \\
\hline Garut x Batur & 1 & $86.00^{\mathrm{a}}$ & $6.44^{\mathrm{a}}$ \\
\hline Sex & & & $7.49^{\mathrm{b}}$ \\
\hline Male & 40 & $44.52^{\mathrm{a}}$ & $6.99^{\mathrm{a}, \mathrm{b}}$ \\
\hline Female & 91 & $35.69^{\mathrm{b}}$ & $9.75^{\mathrm{a}}$ \\
\hline Age (Incisor errupted) & & & $4.50^{\mathrm{b}}$ \\
\hline I-0 & 64 & $28.25^{\mathrm{d}}$ & $6.90^{\mathrm{a}, \mathrm{b}}$ \\
\hline I-1 & 4 & $49.25^{\mathrm{c}}$ & $6.79^{\mathrm{a}, \mathrm{b}}$ \\
\hline I-2 & 5 & $45.00^{\mathrm{c}}$ & \\
\hline I-3 & 6 & $62.83^{\mathrm{a}}$ & - \\
\hline I-4 & 34 & $60.88^{\mathrm{a}, \mathrm{b}}$ & $8.5^{\mathrm{a}}$ \\
\hline Wool distribution & & & $6.7^{\mathrm{a}}$ \\
\hline 7 & 1 & $47.0^{\mathrm{a}}$ & \\
\hline 9 & 24 & $43.5^{\mathrm{a}}$ & $40.8^{\mathrm{a}}$ \\
\hline 0 & 88 & & \\
\hline
\end{tabular}

Note: different letter within sub category means significant different $(\mathrm{P}<0.05)$

The data showed that Batur sheep has the potential as wool producer, eventhough the products may not be used for apparel. The average staple length of magra sheep in India was $6.26 \pm 0.04 \mathrm{~cm}(\mathrm{n}=2073)$ with significant influence of sire used, period of shearing, and season of shearing, whereas sex did not show significant contribution [9]. This data showed that wool length of Batur sheep is almost similar than that of Magra sheep in India. In that paper, the correlations between growth and wool quality traits in Australian dual purpose sheep (Merino x Merino; Corriedale x Merino and White Suffolk x Corriedale) fed canola and flaxseed oil. The supplementation of both oil do not have any significant effect to wool characteristics, include of clean fleece yield (CFY), fibre diameter (FD), fibre standard deviation (FSD), comfort factor (CF), fibre curvature (FC) and spinning fineness (SF), respectively. Oil supplementation is meant to replace some feed ingredients (energy source) which is considerable expensive, and exploring other sources meant to improve efficiency for the management of dual purpose sheep, as wool producer and also as meat producer. On the other hand, wool characteristic (CFY, FD, FSD, CF, FC and SF) was significantly affected by breed as well as significant influence of gender to FSD but not to any other wool characteristics, where wethers has lower FSD compared to ewes. 
Heritability estimates [10] of wool production at 1st, 2nd and 3rd shearing in single born ewes of Katchi sheep were $0.42 \pm 40.271,0.258 \pm 0.250,0.270 \pm 0.18$, respectively. On the other hand, the heritability estimates for 1 st and 2nd shearing were observed $0.803 \pm 0.54$, and $0.117 \pm 0.33$, respectively in twine born ewes. Along with that , [11] reported many factors influence the yield and quality of wool, such as breed type, body weight, feeding management, surface area of sheep body.

If there are possible market for wool production and procesing, farmer institution has to be strengthen in order to accommodate the wool shearing in regular periods, early processing of wool and seeking for market possibility.

Therefore, ram selection is very important in order to maintain the body weight as well as the wool production. Not only that, the management of Batur sheep can be improved by processing the manure as organic fertilizer, processing horticulture by products as feed. However, one has to note is the time allocation by the farmers, because managing horticulture is very timely and possibly only limited hours are available to care for the sheep.

\subsection{The influence of breed on body weight}

The average body weight of the sheep was $41.39 \mathrm{~kg}$ with significant influence $(\mathrm{P}<0.05)$ of farmers, breed, sex and age. The significant influence of farmers on the body weight of the sheep can be due to the daily management practiced by the farmers, the type off feeds given to the animals and how the farmers control the mating of the sheep (only to the best rams in the population). The body weight of 6 months old batur sheep was around $25-30 \mathrm{~kg}$ [12] with average daily gain was from $68.67 ; 62.86 ; 82.67$ and $54.69 \mathrm{grams} / \mathrm{head} /$ day for lambs that received feed using $0.3 \% \mathrm{MOL} ; 0.5 \% \mathrm{MOL} ; 0.7 \% \mathrm{MOL}$ and without using MOL. The results of the study showed that giving MOL $0.7 \%$ to sheep feed gave the best average daily gain and gave the highest $\mathrm{BC}$ (benefit over cost) ratio value (1.16) compared to lambs received MOL $0.3 \%(0.87)$; MOL $0.5 \%(0.90)$; and without using MOL (0.60), respectively. The calculation also includes the cost of manure processing, the price of wool and the growth value of sheep.

The breeds of sheep has also significant influence $(\mathrm{P}<0.05)$ to the body weight with the heaviest body weight was found in crossing between Garut and Batur sheep $(86 \mathrm{~kg})$, then followed by the body weight of Batur sheep (41 kg), crossing between Texel and Batur sheep (31 kg) and crossing between Suffolk and Batur sheep $(27 \mathrm{~kg})$. Those data is of interest since the body weight of crossing between Garut and Batur outstanding the other type of crossing, eventhough the number is only one and could be that this is the ram used for mating.

The average body weight of male sheep was higher ( $44.52 \mathrm{~kg}$ ) compared to the female body weight $(35.69 \mathrm{~kg})$. Different type of gender has significant influence to the body weight $(\mathrm{P}<0.05)$ which is a general knowledge that male hormone has strong influence to the body weight compared to the female.

The age of sheep in this study has significant influence $(\mathrm{P}<0.05)$ to the body weight, where sheep with I-0, I-1, I-2, I-3 and I-4 has average body weight of $28.25 \mathrm{~kg}, 49.25 \mathrm{~kg}$, $45 \mathrm{~kg}, 62.83 \mathrm{~kg}$ and $60.88 \mathrm{~kg}$, respectively. In this study, the sheep body weight was lower than the report by [1] as well as [2], when sheep honoured the certificate as local breed. Therefore, efforts have to be focused on the selecting the best individuals in the population and dispose only the lower classifification of sheep in the population. For instance, sheep with wool distribution less than 7 should be excluded from the population, however, individuals with wool distribution score of 0 has to be kept intensively. The ram selection is also of important, since rams will pass on the genetic merit to the off springs. Therefore, rams with wool distribution score of 0 should be used for the mating. 


\section{Conclusions}

From this study, it can be concluded that most of the Batur sheep (99\%) has wool distribution along the body with the score of 0 and score of 9 for all age level. Eventhough only small percentage (7.1\%) of Batur sheep has been crossed to other breeds of sheep, this practices has to be tightly monitored in order to keep the Batur sheep as one of the registered sheep in the country.

Acknowledgement. We thank the farmers group of Maju Jaya, that allow us to collect the data on the Batur sheep as well as a great appreciation to the Coordinator of Livestock Service of Banjarnegara District. The study was able to be conducted using national budget of APBN 2018-2019 under the title of Coordination of Animal Genetic Resources granted to the Indonesian Centre for Animal Research and Development, Indonesian Agency for Agriculture Research and Development, Ministry of Agriculture.

\section{References}

1. Ibrahim, I.G.S. Budisatria, R. Widayanti, B.A. Atmoko, R. Yuniawan and W.T. Artama. Adv. Anim. Vet. Sci, 8, 1028-1033 (2020)

2. Directorate General of LIvestock and Animal Health (2021). Downloaded on Juni 13, 2021.

3. J. Jakaria, M.S.A. Zein, S.Sulandari, S. Subandriyo and M. Muladno. JITAA, 37, 1-9 (2012)

4. Guang-Wei Ma, Yan-Kai Chu, Wen-Jian Zhang, Fei-Yue Qin, SongSong Xu, Hua Yang, En-Guang Rong, Zhi-Qiang Du, Shou-Zhi Wang, Hui Li and Ning Wang. PLOS ONE, 12, 1-12 (2017)

5. K. Umizakiah, M. Yamin and M.S. Soenarno. JIPTHP, 2, 243-250 (2014)

6. Bell M, I Inounu, Subandriyo, B Setiadi, B Tiesnamurti, GE Bradford and P Sitorus. Working Paper No 23 (1983)

7. SAS.10. SAS Institute Inc., Cary, NC, USA (2002)

8. H. Singh, G.C. Gahlot, H.K. Narula, U. Pannu and A. Chopra. Vet. Pract, 19, 119-122 (2018)

9. A.E.O. Malau-Aduli, D.V. Nguyen, H.V. Le, Q.V. Nguyen, J.R. Otto, B.S. MalauAduli, and P.D. Nichols. PLOS ONE, 14, 1-12 (2019)

10. R.R. Kaleri, H.A. Kaleri, A. Kaleri, S.R Ali Shah, M.A. Jalbani, A. Marri, F. Ashraf, A. Karim, and A.G. Bugti. Sci.Int.(Lahore),29, 699-701 (2017)

11. B.W.B. Holman and A.E. Malau-Aduli. ARRB, 2, 1-14 (2012)

12. V. Malik and Muryanto, M. JP2TP, 22, 143-150 (2020) 